\title{
Exploring the Effect of STEM Education on the Motivations and Epistemological Beliefs Related to Science Among Talented and Gifted Students
}

\author{
Dilara Akpınar \& Sema Altun Yalçın \\ Erzincan Binali Yildirim University, Erzincan, TURKEY
}

Received: 1 November 2021 - Accepted: 18 December 2021 • Published Online: 28 December 2021

\begin{abstract}
The research is aimed to explore the effect of STEM education on the motivations and epistemological beliefs related to science among talented and gifted students. A mixed research method was employed in collecting the data of the research. The sample of the research consisted of $205^{\text {th }}$ and $6^{\text {th }}$ grade students who were diagnosed to be talented. Before the activities, the Epistemological Beliefs Questionnaire and the Motivation Scale for Science Learning were applied to the students. The reflective journals were asked to fill in reflective journals after each activity and individual interviews were conducted after all activities were completed. A significant difference was found between the Epistemological Beliefs Questionnaire and the Motivation Scale for Science Learning pre-test and post-test scores at the end of the research. With the conducted interviews and results from the journals, positive changes were observed in students' self-confidence, motivation, and attitudes towards science lessons in training.
\end{abstract}

Keywords: STEM, epistemological beliefs, motivation scale for science learning, gifted students.

\section{Introduction}

In line with the needs that came into existence in the 21st century that we are in, the trends towards technology and scientific studies have increased. These trends have brought about a global economic, scientific and technological race between countries and necessarily directed the countries to revise their education system and make reforms (Aydın, 2011; Dönmez, 2020). It is noticed that the countries try to create a productive society and to create such a social structure, it is stated that there must be qualified individuals who will grow up are individuals who think, question, research, wonder, problem solve, question, and discover in accordance with 21st-century skills (Bybee, 2011; Koştur, 2017; Akgündüz et al., 2015; Sanders, 2009). To provide this, especially The United States of America and The European countries focus on STEM education and try to integrate it into their education system (Lacey \& Wright, 2009). STEM is an educational approach that consists of the initials of the words Science, Technology, Engineering, and Mathematics. STEM education aims to use these four disciplines in the education field with the integration of each other (Maryland, 2012; Gonzalez \& Kuenzi, 2012; Moomaw, 2013). In STEM education, student analyses the situation determine the problem, collects information, produces authentic ideas, offers solutions to the problems and create and test models for the solution in the process, evaluate the situation (American Association for the Advancement of Science [AAAS], 1993; NAE \& NRC, 2009; NGSS, 2013; NRC, 2012). In such an educational environment, it is

(C) Authors. Terms and conditions of Creative Commons Attribution 4.0 International (CC BY 4.0) apply. Correspondence: Dilara Akpınar, Erzincan Binali Yildirim University, Science Institute, Erzincan, TURKEY. E-mail: akpnrdilara@gmail.com. 
crucial to give education to gifted students (Barış \& Ecevit, 2019). Gifted students who have great potential will contribute to the development of science and technology. Thus, it will be ensured that they play a critical role in the development of the country and its economy (Banks \& Barlex, 2014). With STEM education, educational facilities suitable for the potentials of the gifted students are provided. Thus, it enables to uncover of the potentials that existed among the gifted students accurately and ensure to develop their current potentials (Barış \& Ecevit, 2019). STEM Education has the qualifications to meet the different education that is required for gifted individuals (Kanl \& Özyaprak, 2015). An effective STEM education attaches great importance to students' interests and experiences, based on their existed knowledge, engages them in the practice of science and maintains their interest in STEM (NRC, 2011). In addition, it helps gifted students to capture the nature of STEM disciplines, to function as a scientist, and to be productive as soon as possible (Kanlı \& Özyaprak, 2015). Teaching the STEM field courses with the interdisciplinary integration approach for gifted students enables the students' holistic learning (Steenbergen-Hu and Olszewski-Kubilius, 2017). STEM education may offer an integrated and differentiated learning opportunity to gifted students. Because, activities that reveal their talents and allow them to think multidimensionally can be carried out while doing STEM education (Altun Yalçın, 2019; Özçelik \& Akgündüz, 2018). In addition, that the STEM attitude levels of gifted students are generally positive and that gifted students are interested in STEM career professions have been determined (Bircan and Köksal; 2020). Besides, these students' interests in the professions in the STEM field must be determined and they should be directed in their early ages (Özçelik \& Akgündüz, 2018).

Epistemological belief is an indicator of the systematic structure of the bond and relationship between the structure of knowledge and the individual's belief system. It includes the contexts such as the source of the information, its accuracy, the creation, verification, and acceptance of the information by the individual (Schommer, 1990). Therefore, there is a relationship between learning of the information and the epistemological belief (SchommerAikins, 2002). A relationship was also found between the epistemological belief and academic performance and their understanding levels (Schommer, 1998), attitude (Deryakulu \& Büyüköztürk, 2005), intrinsic motivations, and self-efficacy (Ricco, Pierce, \& Medinilla; 2010) with students' science achievements (Braten \& Ferguson, 2014). In addition, in the study conducted by Lin, Deng, Chai and Tsai (2013) with high school students, they determined a significant relationship between the epistemological beliefs and the motivation related to learning science. Even in the study conducted by Aşut and Köksal (2015), they investigated the relationship between the scientific epistemological beliefs of the students diagnosed to be gifted on their motivation levels related to science learning and science achievement. At the end of the study, a significant relationship was found between their motivation level related to science learning and their scientific epistemological beliefs. It was determined that the task-oriented effort and importance dimensions of motivation towards science learning were positively related to the accuracy and developmental epistemological belief dimensions. Dönmez and Yalmanc1-Yücel, (2020) explored the relationship between STEM attitude and epistemological belief, STEM attitude, and epistemological beliefs of gifted students. At the end of the research, a statistically positive weak relationship was found between the STEM attitude and scientific epistemological belief values. That is, it was concluded that the epistemological beliefs of the students can be a significant predictor of their attitudes related to STEM.

Epistemological belief influences the students' academic achievements (Schommer, 1998); however, this is not the single factor. Motivation is also a significant factor that influences the students' academic achievements (Pintrich, 1999). This case is also effective in learning sciences. The motivation related to learning science has a relationship with self-efficacy, the value of learning science, the main purpose of learning, and the strategy used by the learner (Tuan, Chin \& Shieh, 2005). The motivation towards learning science is effective in students' structuring of science concepts, being aware of the purpose of learning that concept, and the significance of learning (Pintrich, Marx \& Boyle; 1993). The individuals who can control their motivational beliefs 
more efficiently have higher cognitive performances compared with the other individuals (Pape \& Smith, 2002; Schunk \& Zimmerman, 2011). To increase the students' motivations towards science more, increasing their interests, achievements, and attitudes towards science is significant (Kurnaz \& Şentürk Barışı, 2018). It can be claimed that a student with high motivational belief will make effort to learn and satisfy his/her curiosity rather than getting good grades in the science lesson, can overcome even the most complex subjects, can use the knowledge and skills that have been learned in the science lesson in other lessons, and believes that learning this lesson is beneficial for him/her (Schunk \& Zimmerman 2011). Considering this, some studies related to the motivation levels of gifted students, who are seen as future scientists and the heirs of science, towards learning science have been a matter of curiosity, have been conducted. As the literature was reviewed, there are even studies demonstrating that gifted students have a high level of motivational beliefs (Aşut, 2013) and have low motivation (Sak, 2010) towards learning science. For this purpose, laboratory, project, and computer-assisted science education support the desire and determination of gifted students towards science lessons (Hoover, 1989). In the study conducted by Mustafa Kahyaoğlu and Ata Pesen (2013), the relationship between the learning styles of the gifted students and their motivation styles and their attitudes towards science and technology courses was examined. At the end of the research, a moderately significant relationship in a positive direction was determined between the attitudes of the gifted students towards science and technology, their learning styles, and their motivations towards science learning.

As the literature was reviewed, it was noticed that the researches on the implementation of STEM education on the gifted/special talented students were insufficient (Özçelik \& Akgündüz, 2018). Although it has been conducted recently, there is a lack of studies focused on a special group of learners such as gifted students (Aşut \& Köksal 2013; Yılmaz \& Çavaş Huyugüzel, 2007). It is crucial to use enriched curriculum content and materials for the education of gifted and talented students (Miedijensky \& Tal, 2016). It is vital to apply STEM education and activities in the development of gifted and talented students' skills by providing an effective teaching environment in meeting their needs (Yoon \& Mann, 2017). Besides, there is a need for various models and a more structured and planned framework for advancement, for certain interventions such as STEM education especially for the gifted students (Kanlı \& Özyaprak, 2015).

In this scope, the study focuses on the effects of STEM and STEM-Based Robotics applications on gifted students' epistemological beliefs and their motivation to learn science.

\section{Method}

A mixed-method was employed in the research. The mixed-method is defined as using and evaluating quantitative and qualitative methods together in the analysis of data (Creswell \& Plano Clark, 2007). Johnson and Onwuegbuzie (2004) defined the mixed method applications as the completion of each other by combining the qualitative and quantitative research techniques, methods, and approaches of the researcher in a single study. The mixed-method used in the research is a parallel mixed method. The purpose of parallel mixed method researches is to combine the qualitative and quantitative data by collecting them jointly and simultaneously. The emerging strengthened result is used (Tashakkori \& Teddlie, 2003). In the parallel mixed design, it is tried to reach a good understanding in line with the main purpose of the research by interpreting the similarities and differences between the qualitative and quantitative findings (Creswell \& Plano Clark, 2011). To determine the gifted students' motivations towards science learning, the Motivation Towards Science Learning scale developed in 2005 by Tuan, Chin, and Shieh, was applied. The Epistemological Beliefs scale was developed by Conley (2004). In addition, the reflective journals prepared by the researcher were applied to the voluntary students after each application. At the end of the research, an interview was held with the voluntary students. The interview and reflective journal questions were prepared by taking the opinions of 
the two academicians who were professionals in STEM education and an academician dealing with gifted students. In preparing these questions, it was tried to pay attention to the preparation of the research in accordance with the purpose of the research. The scales used in the research were tried to be prepared in line with the sub-dimensions and the behaviors that the scales aim to measure. To determine the effect of STEM Activities on the gifted students' Motivations Towards Science Learning, the questions "Have STEM activities changed your attitude towards Science? Why?" and "Did STEM Activities give you an idea about the application areas of science subjects? Why?" were asked to in the interview. In the reflective journal, to determine the effect of each STEM Activity on students' viewpoints on science and knowledge, and their career choices in science. "Have STEM Activities changed your viewpoint on science and knowledge? Why?" and "Did these activities contribute to your choice of profession in the field of science? Why?" The purpose of these questions is to uncover the effects of these activities on students' perception, attitude, choice of profession, and understanding of science, that is, its application areas. To determine the effect of STEM activities on the gifted students' Epistemological Beliefs, the questions "Did STEM Activities affect your deduction and prediction skills? Why?", "Have you thought about doing research on activities and improving yourself? Why?", "Did these activities help you produce the design of a shape?", "Can you design and build your products?" and "Would you like to present the products you made at the event again? Why?" were asked during the interview. In addition, to determine the effect of each STEM activity on their epistemological beliefs, the questions "If you had the chance to change the materials you used for STEM Activities, how would you design the same activity?", "What do you think you would do if you had the chance to improve our activity? You can show it with a drawing" and "What kind of idea did you have when you first saw the materials?", "Have you thought about creating products from these materials at that moment? The purpose of asking these questions was to reveal the accuracy of knowledge, the development of knowledge, the source of knowledge, and the verification of knowledge are affected by these activities, which the epistemological beliefs scale tries to measure. Thus, it was tried to determine the trends and purposes of the students in developing, proving, confirming, and validating the knowledge experience they have acquired during these activities

The research was carried out with 20 special talented/gifted students who were under education at $5^{\text {th }}$ and 6 th class levels. The participant selection does not represent the universe in the feature of the research. In purposive sampling, it is possible to examine the situation in depth through a small sample. Therefore, it was considered to be appropriate to select the participants with the purposive sampling (Yıldırım \& Şimşek, 2011). The ethical principles were taken into consideration in the research, therefore, the teachers' names were not used. The teachers were coded as T1, T2, T3... T10. In the research, the special talented/gifted students have applied the STEM and STEM-based robotic activities for 10 weeks. These activities were applied with simple materials and robotic Legos that can be found everywhere. It was taken into account that the STEM activities would be held with the materials that they could easily find around even with the items that can be considered as waste. It was given the importance that these activities include different structural logic and content. For instance, 4 types of motors were used in the simple circuits that students would create (geared DC motor, gearless DC motor, brushless DC motor, and RPM motor) and they produced different systems that can function as a motor. The STEMBased Robotics activities were based on the logic of building machine-style structures that they encounter in daily life with special Legos and coding them. Electronic components such as sound sensors, light sensors, smoke and heat sensor, electronic components such as motor, speaker, microphone, lamp, the digital brain can be attached to these Legos. Thus, the students would both make workable prototypes of the machines they see around them, learn what components and elements they include while making them, and also experience how they work by coding. 
Table 1. Application content

\begin{tabular}{|c|c|c|c|}
\hline Week & $\begin{array}{l}\text { Course } \\
\text { Hour }\end{array}$ & Activity Name & Activity Purpose and Content \\
\hline 1. & 2 & $\begin{array}{l}\text { Pre-test } \\
\text { Application }\end{array}$ & $\begin{array}{l}\text { "Motivation Scale for Science Learning" and "Epistemological Belief } \\
\text { Questionnaire" }\end{array}$ \\
\hline 2. & 2 & Traffic Light & $\begin{array}{l}\text { This activity is carried out with a carton, tin can of Coke, } 3 \text { LEDs, and batteries. } \\
\text { The main purpose of this activity is to use the tin can as the contactor switch. } \\
\text { The students will make the red, yellow, and green light up in sequence in this } \\
\text { activity. There must be at least } 3 \text { contactor switch, however, it is not included } \\
\text { in the materials. The students will solve this problem with the way of a solution } \\
\text { that they find themselves; that is, they need to design the can tin in such a way } \\
\text { as to do the duty of } 3 \text { contactor switches. }\end{array}$ \\
\hline 3. & 2 & $\begin{array}{l}\text { The Car with } \\
\text { Mousetrap }\end{array}$ & $\begin{array}{l}\text { They need to design a car working with a mousetrap. The main purpose of this } \\
\text { activity is to design the mousetrap in a way to be used as a motor and develop } \\
\text { their cars to go to the farthest. To make an activity, they will use the simple } \\
\text { materials that can be easily found around; that is with plastic bottle cover, } \\
\text { pipette, stick, string, CD. }\end{array}$ \\
\hline 4. & 2 & Robot Spider & $\begin{array}{l}\text { They will build a robot spider with a motor, a contactor switch, battery, and } \\
\text { wire pieces. The students are asked to learn how to build a simple electrical } \\
\text { circuit and create a moving spider. Thus, they are expected to design and run } \\
\text { a spider that will move with a motor. }\end{array}$ \\
\hline 5 . & 2 & Non-tipping CD & $\begin{array}{l}\text { It is expected from the students to design the CD in a way to stand upright } \\
\text { without collapsing and thus dance. For this, they were allowed to use only } 1 \\
\mathrm{CD}, 1 \text { small CD, } 1 \text { motor, } 1 \text { battery, and } 1 \text { contactor switch. It is aimed at the } \\
\text { students, in this activity, both learn to create a different system with a simple } \\
\text { circuit and learn to establish a system in which the CD can dance upright } \\
\text { without being knocked down (even if kicked). }\end{array}$ \\
\hline 6. & 2 & $\begin{array}{l}\text { The money } \\
\text { swallowing } \\
\text { piggy bank }\end{array}$ & $\begin{array}{l}\text { It is aimed at the students to make a money swallowing piggy bank with } 1 \\
\text { motor, } 1 \text { contactor switch, battery, wire, and carton. }\end{array}$ \\
\hline 7 . & 2 & $\begin{array}{l}\text { The snake with } \\
\text { remote control }\end{array}$ & $\begin{array}{l}\text { The students are expected to make a snake with remote control with } 2 \text { motors, } \\
2 \text { contactor switches, } 2 \text { bottle covers, and cartons. The students designed both } \\
\text { a remote control system with simple circuits and a snake system that can } \\
\text { move. In this way, they were able to move the snake back, forward and right, } \\
\text { left. }\end{array}$ \\
\hline 8. & 2 & Traffic Light & $\begin{array}{l}\text { It is expected the students design a traffic light with legos and code them. In } \\
\text { addition, by giving different problem situations, it is ensured that they create } \\
\text { traffic lights that work in the appropriate function for these situations. }\end{array}$ \\
\hline 9. & 2 & The Carousel & $\begin{array}{l}\text { They are expected to design the Carousel system that they ride in the } \\
\text { amusement parks with its whole parts using the legos. Thus, they were } \\
\text { ensured to create the working systems, the parts, and the components of those } \\
\text { systems. It is also provided that they understand how these components work } \\
\text { and their role in the system. In addition, they made it work as they wanted and } \\
\text { automatically by coding this carousel. }\end{array}$ \\
\hline 10. & 2 & $\begin{array}{l}\text { Washing } \\
\text { Machine }\end{array}$ & $\begin{array}{l}\text { The students were expected to design the prototypes of the washing machines } \\
\text { that are used in daily life with legos. Thus, it was aimed to build all the parts } \\
\text { and functions that a washing machine consists of and help them to understand } \\
\text { their duties. In addition, they were enabled to operate as they desired by } \\
\text { coding the washing machine. During the coding, the digital brains enabling } \\
\text { the washing machine used in daily life work were used. Thus, it was tried to } \\
\text { ensure that the students were coding and operating a real washing machine. } \\
\text { For instance, the washing machine does not work when its door is open, and } \\
\text { when its door is closed, the lamp lights up and codes for it to work at the } \\
\text { desired speed, duration, and performance. }\end{array}$ \\
\hline 11. & 2 & Hand dryer & $\begin{array}{l}\text { It was aimed the students to design the prototype of the hand dryer they used } \\
\text { in daily life with legos. Thus, it was aimed that all parts and functions that } \\
\text { make up the hand dryer are operational and they understand their duties. In } \\
\text { addition, they were ensured to operate as they wished by coding the hand } \\
\text { dryer. During the coding, the digital brains enabling the hand dryer used in } \\
\text { daily life work were used. }\end{array}$ \\
\hline 12. & 2 & Post-test & $\begin{array}{l}\text { "Motivation Scale for Science Learning" and "Epistemological Belief } \\
\text { Questionnaire" }\end{array}$ \\
\hline
\end{tabular}

In the research, the data were analyzed with the paired samples t-test among the parametric tests as the Motivation Scale Towards Science Learning and the Epistemological Beliefs Questionnaires provided the normality. The content analysis was applied in the analysis of the qualitative data. Cohen, Manion and Morrison (2007) defined the content analysis applied in 
the mixed method researches as categorizing the available texts, making comparisons, and ensuring the organization of the data. The data obtained with the interviews held and reflective journals were included in the evaluation after they were analyzed. For this, similarities and differences were determined by creating the codes and categories of the results that emerged from the journals performed with the interviews and activities with students. The frequency situations in which these concepts were repeated were determined. These analyses were performed by the two researchers at different times. It was taken into account that these researchers had taken the qualitative data analysis course. In giving the final form to the analysis, the formula developed by Miles and Huberman (1994) were used. According to the formula, (Reliability = Consensus / Consensus + Disagreement) the fit reliability coefficient between the researchers was found as o,84 in the analyses (Miles \& Huberman, 1994). While the expressions of validity and reliability are used in quantitative researches, in qualitative researches the expressions such as credibility, the accuracy of results, and competence of the researcher are mostly used. Therefore, the validity and reliability of the qualitative researches are provided with the concepts of credibility, consistency, generalizability, and verifiability (Krefting, 1991). The data and analyzes were presented to the participants being investigated for the credibility of the study. Audio recordings, which were recorded, were transcripted. Besides, different researchers' opinions were also applied in evaluating the data. To increase the reliability, the participants were selected from the voluntary students. Participants' names were coded in accordance with ethical rules. Voice recordings were deleted.

\section{Findings}

The data, obtained with the Motivation Scale for Science Learning used to determine whether the opinions of the experimental group, whom the STEM education was held with, related to the Science Learning, were subjected to the paired samples t-test and the results reached are presented in the table below.

Table 2. Motivation Scale for Science Learning t-test results

\begin{tabular}{lcccccc}
\hline Measurements & $\mathbf{N}$ & $\overline{\boldsymbol{X}}$ & $\mathbf{S s}$ & $\mathbf{t}$ & Sd & $\mathbf{p}$ \\
\hline Pre-test & 15 & 127.4000 & 20.16999 & & & \\
Post-test & 15 & 145.0000 & 14.89487 & & & .000 \\
\hline
\end{tabular}

The Paired samples t-test results conducted between the pre-test and post-test scores related to the Motivations for Science Learning of the students who were under education at the Science and Art Center are presented in Table 3.1. As a result of the paired samples t-test was applied to determine whether there was a difference between the averages of the data collected with the self-regulated learning strategies scale applied before and after these applications were implemented to the 15 gifted students who were investigated in terms of whether there were STEM activities had any effect on the Motivations for Science Learning among the special talented and gifted students, a significant difference was found between the pre-application score average $(\overline{\boldsymbol{X}}$ Pre-test $=127,4000)$ and post-application score average $\left(\overline{\boldsymbol{X}}_{\text {Post-test }=145,0000}\right)\left(\mathrm{t}_{15}:-3,383, \mathrm{p}<.05\right)(\mathrm{Can}$, 2016). Thanks to this significant difference, it was observed that STEM activities had positive effects on the motivations for science learning among the special talented and gifted students. 
Table 3. Epistemological Belief Questionnaire t-test results

\begin{tabular}{lcrrccc}
\hline Measurements & N & $\overline{\boldsymbol{X}}$ & Ss & t & Sd & p \\
\hline Pre-test & 15 & 85.2000 & 16.29724 & & & \\
Post-test & 15 & 108.8000 & 11.60788 & -4.383 & 20.85 & .001 \\
\hline
\end{tabular}

The paired samples t-test results performed between the pre-test and post-test scores related to the Epistemological Beliefs of the students who were under education at the Science and Art Centre are presented in Table 5.2 below. As a result of the paired samples t-test was applied to determine whether there was a difference between the averages of the data collected with the Epistemological Beliefs Scale applied before and after these applications were implemented to the 15 gifted students who were investigated in terms of whether there were STEM activities had any effect on the Epistemological Beliefs of the special talented and gifted students, a significant difference was found between the pre-application score average $\left(\overline{\boldsymbol{X}}_{\text {Pre-test }}=85,2000\right)$ and the postapplication score average $\left(\overline{\boldsymbol{X}}_{\text {Post-test }=108,8000}\right)\left(\mathrm{t}_{15}:-4,383, \mathrm{p}<.05\right)(\mathrm{Can}, 2 \mathrm{2016})$. Thanks to this significant difference, it was observed that the given educations contributed positive effects on the epistemological beliefs of the special talented and gifted students.

\section{Qualitative findings}

The students' answers to the interview questions were analyzed and separated into codes and categories.

When the answers of the special talented students to the question "Have STEM activities changed your attitude towards Science?”, only the category of viewpoint towards science and science was formed. In this category, the codes I already liked $(\mathrm{f}=5)$, I liked it more $(\mathrm{f}=3)$ were formed. The students generally stated that they had already loved science much. However, the students claimed that the science course was no longer boring thanks to these activities and the courses were more enjoyable. They stated that science became more enjoyable with the training and they enjoyed it. Some students' answers to this question are as below:

“....It was a bit boring before, now ... entertaining...." (S3)

“...towards science ... changed ..... we even made a washing machine out of a lego or

a lego-like piece. I think it changed..... I liked it more ....." (S8)

As the answers of the special talented students to the question "Did STEM Activities give you an idea about the application fields of science subjects?" were analyzed, the category of developing their knowledge category $(\mathrm{f}=8)$ was formed. In this category, the codes undecided $(\mathrm{f}=2)$, finding a solution $(\mathrm{f}=2)$, no $(\mathrm{f}=3)$, and repeating what they learned $(\mathrm{f}=1)$ were formed. They claimed that, in the code, they were not decided about, they did not have a definite idea, and in the solution-oriented code, they came up with ideas for solving the problems that they come across. In the code of repeating what they learned they defined what and how the activities were created. Some student answers are as follows:

“....If I become a vehicle engineer in the future.... as you know the cars have difficulty in parking, one wheel will turn sideways, then as you hit the gas it will go straight. I want to make it...." (S2)

“....I don't know but I believe I will in the future...” (S1)

As the gifted students' answers to the question "Did inference improve prediction skills? How has development been achieved?" were analyzed the category of predicting and yes and no codes under this code were created. In the code "yes" ( $\mathrm{f}=5)$, the students, claiming that it 
had developed their skills, stated that they reached the result more quickly by determining what they would do in their minds while combining the parts during the realization of the operations in the activities. On the other hand, the students in the code group of "no" ( $\mathrm{f}=3)$ stated that they had already had these skills and that the activities did not develop them. Some of the students' answers are as follows.

“.... Yes. The questionnaires I filled asked my prediction. That is yes, it helped to develop. For instance, I think I'm speeding up my work when attaching it to something by predicting it earlier ...” (S2)

“...I did not develop, I had already had inferencing, predicting, it did no develop...” $(S 7)$

When the gifted students' answers the question "Have you thought about doing research on activities and improving yourself?", "Have you ever thought of writing a project relevant to the activities you performed?" were analyzed, the category of developing knowledge was formed. This category consists of yes $(f=2)$, no $(f=5)$ and not decided $(f=1)$ codes. It was noticed that the code "no" was expressed more in terms of the students' developing their products. The students claimed that they did not want to add anything to what they had learned. On the other hand, the students expressing the code "yes", generally claimed that they wanted to work to find solutions to the problems they encountered in the future. The undecided students (not decided) stated that they have not thought about developing themselves in this field, maybe they do not have a decision that they can do something in the future. Some student answers are as follows:

“.....no, because they do their best to teach us everything...” (S4)

“.... I haven't thought about developing myself by searching....” (S5)

As the gifted students' answers to the question "Did these activities help you create the design of a shape? Can you design and build your products?" were analyzed, the category of creating the design was formed. In this category, the codes making prototype (1), better positioning (3), combining the pieces (2) were formed. The students claimed whether the product that they made worked or not, whether it will be useful or not by making a prototype. In the task coded as better positioning, the students stated how they could help to find ways to add to the information they learned from the current study and to create better results in the future. In the category of combining pieces, they expressed that they were trying to reach the right result by considering the processes they designed in their minds how to place the appropriate parts correctly as the student-created. Some student answers are as follows:

“...yes, I can make my designs..... we make mini washing machines with different materials .....even if the washing machine does not wash, at least, I learned how it works.... When I saw them first, I thought how a washing machine was made with them, but we did. That is, if a washing machine can be made with legos, then everything can be made, therefore, I think it improves us...." (S6)

When the answers of the gifted students to the question "If you had the chance, would you like to reveal the products you made at the event again?" were analyzed, the category of being open to innovations was formed. In this category, the students' opinions were collected under the codes of difference (5) and repetition (3). In the difference dimension, the students mostly stated that they wanted to do new, different activities. They stated that they would do the same activities again if there was nothing to do. They stated that they wanted to set and create new useful things by using and developing their knowledge. On the other hand, in the code of repetition, the students claimed that they wanted to do the same activities again. Some student answers are as follows:

“... I want ...I want to do the same activities again...” (S1) 
“...If I had the opportunity, I would attend these activities again. Certainly, because we both have fun and learn. ....no, I think I would make different things.... It would be better and different...” (S5)

\subsection{Answers for the reflective journal}

As the answers of the gifted students to the question in the reflective journal "What kind of idea did you have when you first saw the materials? Have you thought about creating products from these materials at that moment?" were reviewed, the category of predicting the activity was formed. In this category, the codes such as complex (2), ambiguity (19), pessimism (5), creating mechanism (47) were formed. The ambiguity code of predicting the activity category originated from the students' inabilities to figure out exactly how to turn the materials they have into a working mechanism. The pessimism that occurs in students is usually due to not being able to complete the activity or to thinking that they cannot create a complete product on time. In the category of creating mechanism, it was noticed from the answers given by the students that they were going to establish a mechanism, but they were undecided on how it would emerge, they could not predict exactly what some materials would do in that event, and different products emerged from different perspectives than expected. Some of the student answers are as follows:

“...I thought I was going to make a circuit ....” (S2)

“...We thought we'd make a car directly. We didn't understand what to use the mousetrap for at first....” (S8)

In the findings related to the question "If you had the chance to change the materials you used for the activity, how would you design the same activity?", "What do you think you would do if you had the chance to improve our activity? You can show it by drawing", asked the gifted students, the category of creating their design was created. In this category, six codes were formed consisting of changing the materials (48), omitting material (3), unwilling to change (14), I would not want to do (1), taking the easy way (2) and using a different program (1). It was seen from the students' answers that they wanted the materials to be of higher quality, robust, and strong in the change of materials. Because they wanted to ensure that the materials remain strong for a longer period while doing the activities. They added that things like the engine and beads should be larger at the point where they thought it would be more useful. They also stated that they should develop the mechanism they have established in a way that can change the direction of control or movement. Because of the complexity of some activities, they also stated that they should remove some of the materials they used to create a product more simply. Besides, they stated that they wished to make aesthetical decorations. Some student answers are as follows:

“...I would wrap gelatin which reduces friction around the wheel. I would choose lighter sticks ... " (S2)

"....I would make the cardboard we cut more solid instead of gear. I would add a mouth, eye, etc. I' would make at least some legs to the edge to make it look real...." $\left(S_{3}\right)$

From the answers of the gifted students to the question "Has your viewpoint on Science and Knowledge changed as a result of the activities?", the category of mental and 3 codes under this category was formed. These codes are "viewpoint", "associating", and "perception". In the code of viewpoint, the students referred that they had positive attitudes towards Science (41); however, they loved science and knowledge more with this training (28). In the category of association, the students (1) stated that as a result of the activities, their points of view can change positively only if they can conclude with success. With the feeling of competition within and between groups, they claimed that only if they succeeded, they would develop positive situations towards science and knowledge (1). In the code of feeling-thought, the students claimed that some 
activities were difficult for them (1) or would be boring thinking that they would not be able to finish on time (1) and have difficulty (1). However, they thought that the practices in some weeks could be more understandable and complete, and stated that it was good because they enjoyed the training. The structures that seemed complex were perceived by students as boring or difficult, considering that they would not be able to complete the activities carried out during the education process as a task. The students, who claimed the activities as good, stated that it was pleasant to achieve the results they did not expect, as they learned something new. The answers of some students to this question are as follows:

“...It developed a bit more. We can build a mean with simple materials...” (S4)

"...I have already loved science and knowledge much, but these activities increased it a bit bore..." (S2)

In the findings obtained from the question asked to the gifted students "Did these activities contribute to your choice of profession in the field of science? Why?", in the category of the professions they want to choose in the future, totally nine codes consisting of robot technologies (1), related to the science courses (4), lawyer (1), doctor (7), engineer (16), information technologies (1), lawyer basketballer (2) and not decided (8). The students generally selected the professions in the field of science (22). However, they (32) added that the activities helped to have ideas related to the professions in these fields in time. With these activities, they stated that they tended robot technologies, informatics, and engineering (23). Some student answers are as follows:

“...I want to be an electric and electronic engineer. As engineering is entertaining....” (S1)

"....as I want to choose to engineer and still I want to choose a job in this field...."

(S6)

\section{Discussion and result}

At the end of the study, it was determined that the STEM activities carried out with the gifted students had positive effects on the motivations towards science learning among the gifted students and their epistemological beliefs. In addition, the data obtained from the reflective journals and the data obtained from the interviews support this situation. No research has been encountered conducted related to the effect of STEM Education on the motivations and epistemological beliefs of gifted students towards science learning. However, in the study carried out with the students under education in the state schools, Ozan and Uluçınar Sağır (2020) suggested that the STEM applications had positive effects on the science academic achievements, attitudes towards STEM, motivations, the permanence of the knowledge that they learned. In the study conducted by Çakır and Altun Yalçın (2021), it has been determined that STEM Education develops the pre-service teachers' attitudes towards science and science teaching positively. In the study by Yamak et al., (2014), it was observed that the attitudes towards science and scientific process skills of the secondary school $5^{\text {th }}$ class students developed positively thanks to the STEM activities. In some studies, the results supporting this finding were encountered. As a result of these studies, it was found that STEM education was effective in developing the students' positive attitude towards science, increasing their interests and motivations, accordingly increasing their science achievements (Güldemir \& Çınar, 2017). In addition, in the study by Mellat and Lavasani (2011), it was found that the students' epistemological beliefs had positive effects on the motivational factors. In the study by Dönmez and Yalmancı-Yücel (2020), a statistically positive weak relationship was found between the STEM attitude of the gifted students and their scientific epistemological belief values. It can be claimed that this situation can be originated from the positive effect of STEM activities on the motivation and epistemological beliefs of gifted students 
towards science learning, and the positive effect of epistemological belief (Tal, Krajcik \& Bluemenfeld, 2006; Ercan \& Şahin, 2015). Akbaba (2006) defined motivation as the most significant factor in the topic of reaching the student behavior at a desired target in the educational environment. In the data obtained from the reflective journals and interviews applied to the students within the scope of the study, the students claimed that their motivations and attitudes changed positively. The students claimed in their answers related to their attitudes towards science and knowledge, they generally expressed that they had already loved science and knowledge much, but with these activities, science is far from being boring, they have fun, they feel excited and happy. In addition, during the activities, they stated that they could use the knowledge they learned in science in these applications to find solutions to the problems encountered. It was determined that the groups were in competition to participate in the contest held after the activities and tried to be the first, and this increased their purpose and incentive to realize their performance. Besides, the students also referred that they aim to achieve success, to be the first and that they work for this and make an effort. They claimed that they had high selfefficacy, self-confidence in the activities that they performed. Even though the students had difficulties completing the activities on time, they said that they could not give up and that they wanted to go to a solution instead of making excuses. The students expressed that after carrying out such activities, they produced their products in a way they did not expect as a result of the materials they had, and they used their knowledge of science subjects while performing the activities, while they realized it with different designs. The students stated in their journals that they would carry out the activities related to force or circuit elements depending on the question of what kind of product will emerge according to the materials in the activities. In addition, they referred that they did not expect the circuit elements to use it in so many different ways in their journals, that they could not think about how they would create the product they would make from the materials they had at the beginning, but that they were happy and enjoyed the fact that even such an easily obtainable material was moving as a result. These findings directly support the subdimensions Self-Efficacy, Active Learning Strategies, Value of Science Learning, Performance Purpose, Achievement Goal, Encouragement in the Learning Environment of the motivation scale for science learning. In this way, it can be claimed that the STEM activities increase the students' motivations towards science, learning science, their wishes towards applying what they learned; that is, their motivations towards learning science positively. STEM education is a significant factor in terms of concretizing the subjects and increasing motivation in science teaching. At the same time, lessons can be made more interesting and enjoyable by adding mathematics, engineering, and technology to science teaching (Aşut \& Köksal, 2015; Kennedy et al., 2014; Pintrich, Marx \& Boyle; 1993). With the constructivist approach that takes the student at the center, STEM education, which is an interdisciplinary collaboration, creates an education system that improves life skills by changing the individual's viewpoints towards science (Seren \& Veli, 2018). Camcı Erdoğan (2014) in his study, found that the gifted students' attitudes towards science changed positively after the lessons they conducted with a differentiated model in science education. It can be claimed that this situation is valid for the realization of science with STEM activities. That is STEM activities consisting of science direct play a differentiating role in science education for students. İdin and Kayhan (2016) suggest that it is necessary to prepare appropriate teaching programs so that gifted students can use their potential at the highest level, develop their creativity and skills, and realize their potential. In the present study, with the activities adopted and developed for the gifted students, it was tried to help them to use their potential at the highest level, develop their creativity and skills, and realize their potential. Öztürk and Altun Yalçın (2020); STEM education develops that students' problem-solving motivations and skills and enables them to experience the feeling and thought that "I can do - I do". Thus, their selfconfidence and self-efficacy are increased towards the problems they encounter in daily life.

According to the findings obtained from this research, it is realized that the applications consisting of STEM activities affect the development of their skills related to the gifted 
students' epistemological beliefs. The sub-dimensions of the questionnaire used in the study areas are "Certainty of knowledge, Development of knowledge, Source of knowing and Confirmation of knowing". The students, similarly, answered the question in the journals "if they wanted to redesign the activities, how would they design them and what would you do if they wanted to develop them?" that they wanted to strengthen and reinforce the materials to improve the effectiveness and they designed them differently. The students claimed that it was difficult to reach the results of the activities in one go, but they did not give up on starting over and they wanted to try again. They also expressed that they could take different ways to complete an activity to conclude; however, that it was difficult to restart. They claimed that they wanted to reach the result though. With these activities that take place in the interview questions, as the question, would you like to do the research yourself and reveal different things? was taken into consideration, some students stated that they could design themselves by making additions and changes to find solutions to the problems experienced in the future with the information they learned in the activities. In the study conducted by Çakır and Altun Yalçın (2021), it was determined that STEM Education helped individuals the skill and ability to reach knowledge like a scientist, to question and verify the knowledge $\mathrm{s} /$ he has reached, and to develop knowledge by applying knowledge. This case stems from the fact that during STEM education, students constantly experience the process of using existing information, gaining new information, testing new information, and structuring information (Çalik \& Altun Yalçın, 2022). STEM education has great significance in helping the students to develop their interdisciplinary knowledge and skills in different fields and to reorganize their ideas (Honey et al., 2014). With STEM education, the individual applies different methods and techniques to produce appropriate solutions against the problem (Kelley \& Knowles, 2016). They can get rid of traditional methods, look at problem situations from all aspects and with a critical perspective by integrating four skills with STEM, work in cooperation with their peers by communicating effectively, and apply the knowledge they have obtained in their daily lives as well as in their academic life (Kennedy \& Odell, 2014). That is, it is aimed to ensure students with the ability to produce solutions to the problems they encounter in daily life, to think deeply and scientifically (Çepni, 2017).

\section{Suggestion}

STEM; It is an educational approach that focuses on learning science by integrating it with other branches of science or integrating it into lessons. This situation enables students to love science, to increase their motivation and desire to learn science, and to increase their epistemological beliefs. In order to increase students' interest in science and thus increase their academic success, it can be suggested to use STEM Education in classroom and extracurricular activities. It is of great importance to include STEM Education in the education of especially gifted students. Gifted students are the gems of countries. In this case, students should receive the best education. STEM Education gains more importance especially as it increases their epistemological beliefs and motivation towards science learning. Increasing interest of gifted students in science professions and choosing these professions will enable countries to progress economically, technologically and scientifically. In order to achieve this, the education of gifted students should be based on STEM Education.

\section{Acknowledgements}

This research did not receive any specific grant from funding agencies in the public commercial, or not-for-profit sectors.

The authors declare no competing interests. 


\section{References}

American Association for Advancement of Science. (1993). Benchmarks for science literacy. New York: Oxford University Press.

Akbaba, S. (2006). Eğitimde Motivasyon. Kazım Karabekir Eğitim Fakültesi Dergisi, 13, 343.

Akgündüz, D., Aydeniz, M., Çakmakçı, G., Çavaş, B., Çorlu, M. S., Öner, T., \& Özdemir, S. (2015). STEM Eğitimi Türkiye Raporu: Günün Modası Mı Yoksa Gereksinim mi? İstanbul: Aydın Üniversitesi. Retrieved 15 March 2021, from https://www.aydin.edu.tr/trtr/akademik/fakulteler/egitim/Documents/STEM\%20E\%C4\%9Fitimi\%20T\%C3\%BCrkiye\%2 oRaporu.pdf.

Altun, Yalçın, S. (2019). The effect of integrated STEM education on teachers and the opinions of teachers. Journal of Social, Humanities and Administrative Sciences, 2O(5), 948-963.

Aşut, N. (2013). Relationship of gifted students' epistemological beliefs with science achievement and motivation towards science learning. Unpublished master's thesis, İnönü University Institute of Education Sciences.

Aşut, N., \& Köksal, M. (2015). Relationship of gifted students' epistemological beliefs with achievement and motivation towards science learning. Journal of Düzce University Institute of Social Sciences, 2(1), 22-44.

Aydın, M. (2011). Fen ve Teknoloji öğretmenleri için geliştirilen proje tabanlı öğretim yöntemi konulu bir destek programının etkilerinin araştırılması. Unpublished doctoral thesis, Karadeniz Teknik University.

Banks, F., \& Barlex, D. (2020). Teaching STEM in the secondary school: Helping teachers meet the challenge. Routledge.

Barış, N., \& Ecevit, T. (2019). STEM education for gifted student. Necatibey Faculty of Education Electronic Journal of Science and Mathematics Education, 13(1), 217-233.

Bircan, M. A., \& Köksal, Ç. (2020). Investigation of STEM attitudes and STEM career interests of gifted students. Turkish Journal of Primary Education, 5(1), 16-32.

Bråten, I., \& Ferguson, L. E. (2014). Investigating cognitive capacity, personality, and epistemic beliefs in relation to science achievement. Learning and Individual Differences, 36, 124-130.

Bybee, R. W. (2011). Scientific and engineering practices in K-12 classrooms: Understanding a framework for K-12 science education. Science and Children, 49(4), 10-16.

Camc1 Erdoğan, S. (2014). The effect of differentiated science and technology instruction based on scientific creativity on gifted and talented students' achievement, attitude and creativity. Istanbul University (Doctoral dissertation, PhD Dissertation, Institute of Educational Sciences, Istanbul).

Can, A. (2016). SPSS ile bilimsel araştırma sürecinde veri analizi[Data analysis in the scientific research process with SPSS]. Ankara: Pegem Akademi.

Cohen, L., Manion, L., \& Morrison, K. (2007). Research methods in education. Sixth Edition. New York.

Conley, A. M., Pintrich, P. R., Vekiri, I., \& Harrison, D. (2004). Changes in epistemological beliefs in elementary science students. Contemporary Educational Psychology, 29, 186-204.

Cresswell, J. W., \& Plano Clark, V. L. (2007). Designing and conducting mixed method research. London: Sage Publications.

Çakır, Z., \& Altun-Yalçın, S. (2021). The investigation of the effect of Montessori approach-based STEM activities on the problem-solving skills of pre-service preschool teachers. Kuramsal Eğitimbilim Dergisi [Journal of Theoretical Educational Science], 14(2), 93-119.

Çakır, Z., \& Altun Yalçın, S. (2021). The effects of Montessori approach based STEM activities on pre-service teachers' attitudes towards science and science teaching. OPUS International Journal of Society Researches, 17(35), 1895-1924. https://doi.org/10.26466/opus.831879 
Çalik, H., \& Altun Yalçın, S. (2022). The effect of stem and stem-based robotics activities on constructive learning environments opinions of teacher candidates. IBAD Sosyal Bilimler Dergisi, (12), 137163. https://doi.org/10.21733/ibad.948455

Çepni, S. (2018). Kuramdan uygulamaya STEM eğitimi [STEM education from theory to practice] ( $2^{\text {nd }}$ edition). Ankara: Pegem Akademi Yayınları

Deryakulu, D., \& Büyüköztürk, Ş. (2005). Epistemolojik inanç ölçeğinin faktör yapısının yeniden incelenmesi: Cinsiyet ve öğrenim görülen program türüne göre epistemolojik inançların karşlaştırılması. Eurasian Journal of Educational Research, 18, 57-70.

Dönmez, M.C. (2020). Robotik Uygulamalartn Aday Öğretmenlerin STEM Farkındahkları, Fen Öğretmeye Yönelik Öz Yeterlikleri ve Stem'e Yönelik Tutumlar Üzerine Etkileri. Unpublished masters'thesis, Kurşehir Ahi Evran University.

Dönmez, İ., \& Yalmancı-Yücel, S. Y. (2020). Analysis of scientific epistemological beliefs and STEM attitudes of the gifted students. Bartin University Journal of Faculty of Education, 9(3), 515-526.

Ercan, S., \& Şahin, F. (2015). The Usage of Engineering Practices in Science Education: Effects of design based science learning on students' academic achievement. Necatibey Faculty of Education Electronic Journal of Science and Mathematics Education, l(9), 128-164.

Gonzalez, H. B., \& Kuenzi, J. J. (2012). Science, technology, engineering, and mathematics (STEM) education: A primer. Congressional Research Service.

Güldemir, S., \& Çınar S. (2017). Fen bilimleri öğretmenleri ve ortaokul öğrencilerinin STEM etkinlikleri hakkındaki görüşleri. ULEAD 2017 Annual Congress: ICRE, 280-286.

Honey, M., Pearson, G., \& Schweingruber, A. (2014). STEM integration in K-12 education: Status, prospects, and an agenda for research. Washington: National Academies Press.

Hoover, S. M. (1989). The Purdue three stage model as applied to elementary science for the gifted. School Science and Mathematics, 89(3), 244-50.

İdin, Ş., \& Kayhan, N. (2016). European Union countries and primary period gifted-talented students for special education practices in Turkey. Journal of Kirsehir Education Faculty, 17(2), 17-31.

Johnson, R., \& Onwuegbuzie, A. (2004). Mixed methods research: A research paradigm whose time has come. Educational Researcher, 33(7), 14-26.

Kahyaoğlu, M., \& Pesen, A. (2013). The relationship between gifted students' attitudes towards science and technology and their learning and motivation styles. Journal of Giftedness and Education, 3(1), 38-49.

Kanl, E., \& Özyaprak, M. (2016). Stem education for gifted and talented students in Turkey. Journal of Gifted Education Research, 3(2), 1-10

Kelley, T. R., \& Knowles, J. G. (2016). A conceptual framework for integrated STEM education. International Journal of STEM education, 3(1), 1-11.

Kennedy, T., \& Odell, M. (2014). Engaging students in STEM education. Science Education International, 25(3), 246-258.

Koştur, H. İ. (2017). The history of science practices in stem education: Al-Jazari example. Başkent University Journal of Education, 4(1), 61-73.

Krefting, L. (1991). Rigor in qualitative research: The assessment of trustworthiness. American Journal of Occupational Therapy, 45(3), 214-222.

Kurnaz, A., \& Barışık, C. Ş. (2018). Examination of relationship between gifted students' motivational beliefs and creative thinking skills in science course. Milli Ĕ̈itim Dergisi, 47(220), 59-78.

Lacey, T. A., \& Wright, B. (2009). Occupational employment projections to 2018. Monthly Labor Review, 82-109.

Lin, T. J., Deng, F., Chai, C. S., \& Tsai, C. C. (2013). High school students' scientific epistemological beliefs, motivation in learning science, and their relationships: A comparative study within the Chinese culture. International Journal of Educational Development, 33(1), 37-47. 
Maryland State STEM Standards of Practice. (2012). Maryland STEM: Innovation today to meet tomorrow's global challenges. Retrieved on 22 April 2021, from http://mdk12.msde.maryland.gov/instruction/academies/marylandstatestemstandardsofpra ctice.pdf.

Mellat, N., \& Lavasani, M. G. (2011). The role of epistemological beliefs, motivational constructs and Information processing strategies in regulation of learning. Procedia-Social and Behavioral Sciences, 30, 1761-1769.

Miedijensky, S., \& Tal, T. (2016). Reflection and assessment for learning in science enrichment courses for the gifted. Studies in Educational Evaluation, 5o, 1-13.

Miles, M. B., \& Huberman, A. M. (1994). Qualitative data analysis: An expanded sourcebook. Sage.

Moomaw, S. (2013). Teaching STEM in the early years: Activities for integrating science, technology, engineering, and mathematics. Redleaf Press.

National Research Council (NRC). 2011. A framework for $\mathrm{K}-12$ science education: Practices, crosscutting concepts, and core ideas. Washington, DC: National Academies Press.

National Academy of Engineering and National Research Council [NAE \& NRC] (2009). Engineering in K12 education: Understanding the status and improving the prospects. Washington: National Academies Press.

NGSS Lead States (2013). Next generation science standards: For states, by states. Washington, DC: National Academies Press.

National Research Council (2012). A framework for $K$-12 science education: Practices, crosscutting concepts, and core ideas. Washington, DC: National Research Council.

Ozan, F., \& Uluçınar Sağır, Ş. (2020). The effect of stem implementation on attitude towards stem and success in "measurement of force and friction" class. Journal of Kazım Karabekir Education Faculty, 41, 260-275.

Özçelik, A., \& Akgündüz, D. (2018). Üstün/özel yetenekli öğrencilerle yapılan okul dışı STEM eğitiminin değerlendirilmesi. Trakya Üniversitesi Ĕ̆itim Fakültesi Dergisi, 8(2), 334-351.

Öztürk, S. C., \& Altun Yalçın, S. (2020). STEM eğitiminin fen bilgisi öğretmen adaylarının problem çözme becerilerine etkisi. Turkish Studies - Education, 15(4), $2893-2915$. https://dx.doi.org/10.47423/TurkishStudies.43707

Pape, S. J., \& Smith, C. (2002). Self-regulating mathematics skills. Theory Into Practice, 41(2), 93-101.

Pintrich, P. R. (1999). The role of motivation in promoting and sustaining self-regulated learning. International Journal of Educational Research, 31(6), 459-470.

Pintrich, P. R., Marx, R. W., \& Boyle, R. A. (1993). Beyond cold conceptual change: The role of motivational beliefs and classroom contextual factors in the process of conceptual change. Review of Educational Research, 63(2), 167-199.

Ricco, R., Schuyten Pierce, S., \& Medinilla, C. (2010). Epistemic beliefs and achievement motivation in early adolescence. The Journal of Early Adolescence, 3o(2), 305-340.

Sak, U. (2011). An overview and social validity of the education programs for talented students' model (EPTS). Education and Science, 36(161), 213-229.

Sanders, M. (2009). STEM, STEM education, STEM mania. The Technology Teacher, 68(4), 20-26.

Schommer, M. (1990). Effects of beliefs about the nature of knowledge on comprehension. Journal of Educational Psychology, 82(3), 498.

Schommer, M. (1998). The influence of age and education on epistemological beliefs. British Journal of Educational Psychology, 68(4), 551-562.

Schommer-Aikins, M. (2002). Epistemological belief system. Personal epistemology: The Psychology Of Beliefs About Knowledge And Knowing, 105-118.

Schunk, D. H., \& Zimmerman, B. (Eds.) (2011). Handbook of self-regulation of learning and performance. Taylor \& Francis. 
Seren, S., \& Veli, E. (2018). 2005 yılı itibariyle değişen fen bilimleri dersi öğretim programlarında STEM eğitimine yer verilme düzeylerinin karşılaştırılması [Comparison of different levels of including STEM education in science curriculum modified since 2005]. Journal of STEAM Education, 1(1), 24-47.

Steenbergen-Hu, S., \& Olszewski-Kubilius, P. (2017). Factors that contributed to gifted students' success on STEM pathways: The role of race, personal interests, and aspects of high school experience. Journal for the Education of the Gifted, 4O(2), 99-134.

Tal, T., Krajcik, J. S., \& Blumenfeld, P. C. (2006). Urban schools' teachers enacting project-based science. Journal Of Research İ Science Teaching, 43(7), 722-745.

Johnson, R. B., \& Turner, L. A. (2003). Data collection strategies in mixed methods research. A. Tashakkori, and C. Teddlie (Ed.), Handbook of mixed methods in social and behavioral research (pp. 297319).

Tuan, H. L, Chin, C. C., \& Shieh, S. H. (2005). The development of a questionnaire tomeasure students' motivation towards science learning. International Journal of Science Education, 27(6), 639654

Yamak, H., Bulut, N., \& Dündar, S. (2014). 5. Sınıf öğrencilerinin bilimsel süreç becerileri ile fene karşı tutumlarına FeTeMM etkinliklerinin etkisi. Gazi Eğitim Fakültesi Dergisi, 34(2), 249-265

Yıldırım, A., \& Şimşek, H. (2011). Sosyal Bilimlerde Nitel Araştırma Yöntemleri. Seçkin Yayınevi: Ankara.

Yılmaz, H., \& Çavaş Huyugüzel P. (2007). Reliability and validity study of the students' motivation toward science learning (smtsl) questionnaire. İlköğretim Online, 6(3), 430-440. http://ilkögretimonline.org.tr.

Yoon, S. Y., \& Mann, E. L. (2017). Exploring the spatial ability of undergraduate students: association with gender, STEM majors, and gifted program membership. Gifted Child Quarterly, 61(4), 313327. 